\title{
Mosquito mating game could mean buzzkill for Brits
}

Last year, West Nile virus (WNV) claimed the lives of 277 Americans. But while sporadic outbreaks have occurred in southern Europe, no one has yet fallen sick in the UK. One group of British scientists says the key lies in two indigenous mosquito variants and is investigating whether a hybrid of the two could trigger a US-style epidemic.

Although more than 20 species of mosquitoes in the US are infected with WNV, Culex pipiens has historically been the primary culprit. C. pipiens has two known physiological variants-C. pipiens molestus, which bites only people, and C. pipiens pipiens, which bites only birds. For the virus to be transmitted from bird to human-the usual path of infection-the vector must bite both.

Dina Fonseca, an entomologist at the Philadelphia Academy of Sciences, uses rapidly mutating genetic markers called microsatellites to try to differentiate the two C. pipiens variants. C. pipiens molestus is a recently domesticated version of C. pipiens pipiens, Fonseca says. "One possibility is that while in the old world you have this domesticated type and this feral type, both of them got introduced into the US and mated, and you got a hybrid that may behave differently."

Most researchers outside Britain have had no difficulty in mating the two variants in the lab. But in Britain, the two remain isolated in the wild, says Colin Malcolm, a researcher at the University of London. He plans to collaborate with
Fonseca to compare British and American C. pipiens using microsatellites.

Malcolm has been investigating reports of a five-year-long biting nuisance in a village in Clackmannanshire, Scotland. His team found the culprit to be a population of $C$. pipiens molestus breeding in a semiunderground factory. When Malcolm

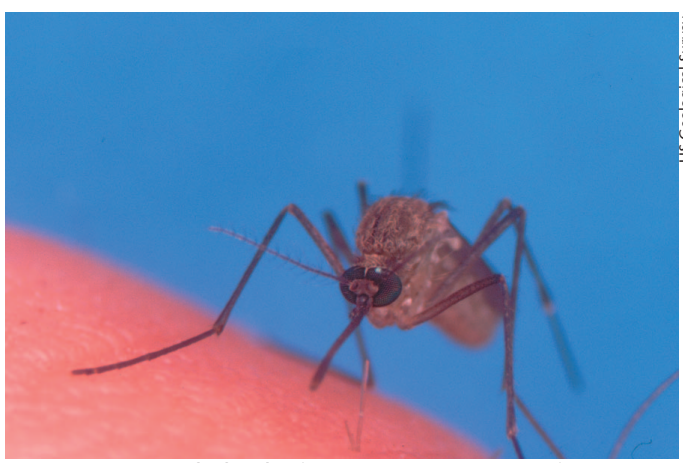

Love stings: A hybrid of two native strains of C. pipiens could bring West Nile virus to the UK.

tested the genotype of the mosquitoes, he found, to his surprise, that about half the population tested positive for an insecticide-resistant haplotype or gene set, $A 2 B 2$, that originated in Africa. Because none of the $C$. pipiens pipiens they tested within a five-kilometer radius of the factory carried the same haplotype, they concluded that the two variants were not interbreeding.

"We are probably benefiting from the fact that in Britain-so far at least-our $C$. pipiens pipiens is very bird-specific," says Malcolm.

In the insecticide-resistant Scottish population-the first of its kind to be de- scribed in Britain-entomologists are dealing with an unknown quantity, says Malcolm. "[The A2B2 haplotype] arrived in Marseilles and we watched it travel north," he says. "That means that we are dealing with a [C. pipiens] molestus that isn't necessarily conforming to characteristics that we might have in Britain."

The continued absence of WNV-related encephalitis or meningitis in Britain is reassuring, Malcolm says. That could be down to the genetic isolation of $C$. pipiens pipiens, or it could be because the birds they are feeding on are not infected. Last October, rumors appeared in the British press that scientists had found antibodies against WNV in dead birds, but the claims have yet to be supported by a paper published in a peer-reviewed journal.

"In a country like this there is relatively little exposure to humans by mosquitoes," says Ernie Gould of the Oxford Centre for Ecology and Hydrology. Gould is one of many researchers monitoring birds for new viruses. "The virus may be circulating in the wild and may be virulent," Gould says, "but it still need not be causing disease."

Most people in Britain have C. pipiens pipiens breeding in their back garden, Malcolm points out. If the virus is in birds, and a hybrid pipiens-molestus subspecies emerges that bites both man and bird, Britain will be as vulnerable as the US.

Laura Spinney, London

\section{French follow US lead... in cancer research, at least}

The French government in March launched a new national plan to boost clinical, basic and epidemiologic cancer research. French President Jacques Chirac announced the unprecedented measure even as the government cut the country's science budget for the second time in six months.

The five-year national plan against cancer will set aside $€ 11.5$ million to coordinate research through the National Institute of Cancer (NIC), a new agency to be supervised by French health and science ministers. The government has said it will increase tobacco taxes to help finance the plan.

The NIC-to be launched next yearwill be similar to the US National Cancer Institute and will be built near Paris, says David Khayat, head of medical oncology at the Paris-based Salpêtrière hospital. The plan is a "great opportunity for France," says Khayat, adding that it will reorganize basic research in oncology. It is also expected to create 2,000 new research positions.

Central to the new scheme are the socalled 'cancéropôles', a network of research units that focus on a few cancer-related topics. The units will have links to cancer healthcare centers to gain access to cancer patients. Although cancéropôles will belong administratively to their home institution, they will have a special status and answer only to the NIC. The NIC will coordinate research in cancéropôles and boost collaborations with industry, particu- larly for clinical trials of new drugs.

The government also plans to create 80 tumor banks with at least 100,000 cancer samples for genetic tumor profiles. Researchers expect to begin assessing data in 2006. In addition to epidemiologic research, such as analysis of risk factors at several levels (environmental, nutritional, occupational and infectious), at least $10 \%$ of patients will benefit from clinical trials. The NIC will ensure a tight control of post-authorization studies of newly approved cancer drugs and enhance academic and hospital training in oncology. For example, the new plan aims to double the number of residents in medical oncology and radiotherapy by 2007.

Xavier Bosch, Barcelona 